\title{
Analisis Protein, Kalsium dan Daya Terima Biskuit Ubi Jalar Ungu (Ipomoea batatas L.) dengan Penambahan Daun Kelor (Moringa oleifera)
}

\author{
Ninna Rohmawati ${ }^{1}$, Mariska Anggraini ${ }^{2}$, Ruli Bahyu Antika ${ }^{3}$ \\ ${ }^{1}$ Universitas Jember, Jln. Kalimantan 37 Kampus Tegal Boto Jember 68121, ninna.rohmawati@gmail.com \\ 2,3 Universitas Jember, Jln. Kalimantan 37 Kampus Tegal Boto Jember 68121
}

\section{Kata kunci: \\ Daun kelor \\ Kadar Protein \\ Kadar Kalsium \\ Daya Terima}

\begin{abstract}
ABSTRAK
Latar Belakang : Pemenuhan kebutuhan zat gizi balita dapat diatasi dengan melakukan pemberian makanan tambahan. Pembuatan makanan tambahan berupa biskuit dapat dilakukan dengan cara memanfaatkan bahan pangan lokal. Upaya ini dilakukan sebagai bentuk diversifikasi produk olahan yang terbuat dari daun kelor yang memiliki banyak manfaat bagi kesehatan. Tujuan : Menganalisis kadar protein, kalsium dan daya terima biskuit ubi jalar ungu dengan penambahan tepung daun kelor sebesar $5 \mathrm{~g}, 10 \mathrm{~g}$, dan $15 \mathrm{~g}$. Metode : Penelitian ini merupakan penelitian eksperimen murni dengan menggunakan Posttest-Only Control Design. Penelitian ini melibatkan 25 ibu balita yang berada wilayah kerja Puskesmas Sumbersari Kabupaten Jember. Hasil : Berdasarkan data hasil uji kadar protein dan kalsium meningkat secara signifikan. Kesimpulan : Daya terima berupa aroma, warna, rasa dan tekstur secara statistik berbeda secara signifikan.
\end{abstract}

\section{ABSTRACT}

Key word: Moringa leaves Protein Levels Calcium Levels Acceptability providing Supplementary Food. Making supplementary food in the form of biscuits can be done by utilizing local food ingredients. This effort is done as a form of diversification of processed products made from Moringa leaves which have many health benefits. Objectives: to analyze the levels of protein, calcium and acceptability of purple sweet potato biscuits with the addition of moringa leaf flour by $5 \mathrm{~g}, 10 \mathrm{~g}$, and $15 \mathrm{~g}$. Method : This study was an experimental research. This type of research was true experimental using Posttest-Only Control Design. This research requires 25 mothers of toddlers in the working area of the Puskesmas Pakusari Jember Regency. Result : Based on data from the test results protein and calcium levels increased significantly. Conclusions : Acceptability in the form of aroma, color, taste and texture was statistically significantly different. 


\section{Pendahuluan}

Masa balita (bawah lima tahun) merupakan golden age yang sangat penting, terutama pada pertumbuhan fisik seorang anak ${ }^{1}$. Kebutuhan gizi balita yang tidak terpenuhi dapat memicu adanya penyakit dan jika terus dibiarkan maka balita akan terjangkit penyakit yang merupakan manifestasi dari adanya penyebab penyakit. Salah satu penyakit yang dapat terjadi dan merupakan manifestasi dari tidak terpenuhinya kebutuhan balita adalah gizi buruk-gizi kurang yang akan berdampak pada pertumbuhan dan perkembangannya. Makanan yang dikonsumsi oleh balita memiliki peranan penting dan akan mempengaruhi kondisi fisik, terutama pada proses pertumbuhan dan perkembangannya. Karena makanan bagi seorang anak, digunakan untuk aktivitas sehari-hari dan proses pertumbuhan². Tingkatan konsumsi energi dan protein merupakan faktor langsung yang berhubungan atau berpengaruh secara langsung dengan status gizi balita, sehingga dapat dikatakan status gizi seorang anak bergantung pada konsumsi makanan sehari-hari ${ }^{3}$.

Salah satu cara yang dapat dilakukan untuk mencukupi kebutuhan balita gizi kurang dengan melakukan pemberian makanan tambahan. Upaya pelaksanaan Pemberian Makanan Tambahan (PMT) ditujukan untuk dapat memberikan zat gizi dan energi bagi balita yang telah terdaftar sebagai penderita gizi kurang atau disebut dengan sasaran ${ }^{4}$. Untuk dapat memenuhi kebutuhan gizinya balita memerlukan makanan yang banyak mengandung protein dan kalsium. Zat tersebut berguna untuk membantu pertumbuhan, pemeliharaan dan perbaikan jaringan tubuh balita ${ }^{5}$. Pembuatan makanan tambahan berupa biskuit yang dapat dilakukan dengan cara memanfaatkan bahan pangan lokal. Upaya ini dilakukan sebagai bentuk diversifikasi produk olahan yang terbuat dari daun kelor yang memiliki banyak manfaat bagi kesehatan semakin bertambah pesat seiring dengan bertambah cerdasnya masyarakat $t^{6}$. Pemilihan bahan dasar ubi ungu pada biskuit dilakukan karena bahan dasar ubi ungu mudah untuk didapatkan. Hasil panen ubi ungu melimpah ruah di Indonesia. Berdasarkan hasil total produksi, Indonesia termasuk penghasil ubi jalar kedua terbesar?.

Konsumsi umbi-umbian ditingkatkan dengan mengutamakan produksi lokal sehingga ketergantungan pada sumber karbohidrat seperti pada gandum sebagai dasar pembuatan tepung dan beras sebagai makanan pokok dapat menurun ${ }^{8}$. Adanya penelitian ini menguji kadar protein dan kalsium pada biskuit berbasis pangan lokal berbahan dasar ubi ungu dengan campuran tepung daun kelor. Kandungan karbohidrat pada ubi jalar ungu sangat tinggi, sementara kandungan protein dan kalsiumnya tergolong rendah rendah. Protein dan kalsium yang tinggi didapatkan dari penambahan bahan makanan sebagai upaya mengoptimalkan pertumbuhan pada balita. Daun kelor merupakan salah satu dari berbagai macam jenis sayuran yang mengandung banyak nilai gizi, terutama protein yaitu sebesar $6,8 \mathrm{~g}$ dan kalsium sebesar 1077mg kandungan tersebut tergolong relatif tinngi dibandingkan jenis sayuran lainnya seperti daun katuk9. Tujuan adanya penelitian ini adalah untuk mengetahui kandungan gizi berupa kadar protein dan kadar kalsium serta daya terima biskuit ubi jalar ungu dengan penambahan tepung daun kelor sebesar $5 \mathrm{~g}$, $10 \mathrm{~g}$ dan $15 \mathrm{~g}$.

\section{Metode}

Jenis penelitian ini adalah penelitian True Experimental, yaitu peneliti melakukan suatu manipulasi terhadap objek penelitian serta adanya control ${ }^{10}$. Pada penelitian ini pemelilihan 
ubi jalar ungu sebagai bahan tambahan dilakukan secara random untuk dapat dijadikan sebagai sampel untuk dapat diproses menjadi tepung dan diolah menjadi biskuit ubi jalar ungu dengan atau tanpa menggunakan penambahan tepung daun kelor pada 4 taraf perlakuan yang berbeda-beda. Penelitian ini menggunakan rancangan posttest dengan kelompok kontrol (posttest only control group design). Biskuit ubi jalar ungu dengan penambahan tepung daun kelor sebesar $5 \mathrm{~g}, 10 \mathrm{~g}$, dan $15 \mathrm{~g}$ dari jumlah seluruh adonan sebesar $175 g$.

Pengujian kadar protein dan kalsium dilakukan di Laboratorium Analisis Pangan Politeknik Negeri Jember, sedangkan untuk pengujian organoleptik kesukaan (hedonic scale test) dilakukan pada 25 ibu yang memiliki anak balita di Kelurahan Sumbersari, Kabupaten Jember. Penelitian dilakukan pada minggu ke dua bulan Mei sampai dengan September 2019.

Ubi jalar ungu yang berasal dari pasar Arjasa, Kecamatan Arjasa Kab. Jember. Tepung daun kelor didapat dari produsen tepung daun kelor yang di produksi oleh KM-2C (Kesilir Maronggih Center Community) di Desa Wuluhan, Kab. Jember. Populasi manusia dilakukan pada balita. Namun karena adanya keterbatasan, dimana balita belum bisa memberikan penilaian terhadap makanan yang dikonsumsi maka dialihkan kepada ibu-ibu yang memiliki anak balita di Kecamatan Sumbersari Kabupaten Jember.

\section{Hasil Dan Pembahasan}

Berdasarkan hasil analisis kadar protein pada biskuit ubi jalar ungu tanpa/dengan penambahan tepung daun kelor dengan 4 taraf perlakuan (X0, X1, X2 dan X3) terlihat bahwa seiring dengan penambahan tepung daun kelor dalam bahan pembuatan biskuit maka kadar protein semakin meningkat. Berdasarkan uji Mann Whitney $U$ Test bahwa keempat sampel memiliki perbedaan yang signifikan yaitu (X0 dan $\mathrm{X} 1),(\mathrm{X} 0$ dan $\mathrm{X} 2),(\mathrm{X} 0$ dan $\mathrm{X} 3),(\mathrm{X} 1$ dan $\mathrm{X} 2)$, (X1 dan X3) dan (X2 dan X3). Terlihat bahwa kadar protein meningkat seiring dengan semakin banyaknya penambahan tepung daun kelor pada biskuit ubi jalar ungu. Hasil uji ini selaras dengan penelitian yang dilakukan oleh Rudianto et al, yang menyatakan bahwa kadar protein dihasilkan pada penelitian sebesar $16,1 \%$. Nilai tersebut telah memenuhi standar menurut SNI No. 01-2973-92 yaitu minimal 9\%. Hal tersebut disebabkan karena porsi karbohidrat digantikan oleh bahan yang disuplementasikan yaitu tepung daun kelor. Semakin banyak tepung daun kelor yang disuplementasikan atau ditambahkan kedalam biskuit maka kadar protein yang ada pada biskuit menjadi tinggi ${ }^{12}$.

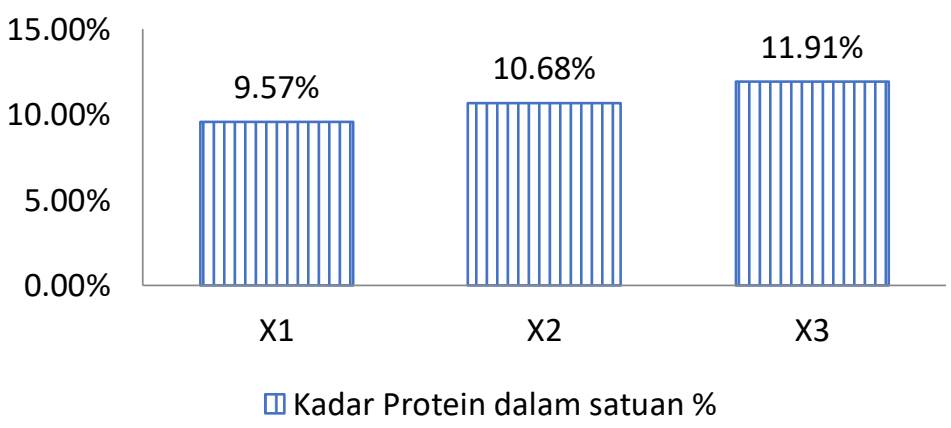

\section{Gambar 1. Kadar Protein dalam 3 Taraf Perlakuan pada Biskuit}

Berdasarkan hasil analisis kadar kalsium biskuit ubi jalar ungu dengan penambahan tepung daun kelor dengan 4 taraf perlakuan $(\mathrm{X} 0, \mathrm{X} 1, \mathrm{X} 2$, dan $\mathrm{X} 3)$ terlihat dengan semakin 
tingginya penambahan tepung daun kelor dalam pembuatan biskuit maka kalsium juga semakin meningkat yaitu sebesar $1889,9 \mathrm{mg}$, 3616,36 mg dan 5159,8 mg per 100g biskuit. Berdasarkan Mann Whitney Test menunjukkan bahwa keempat sampel memiliki perbedaan yang signifikan yaitu (X0 dan $\mathrm{X} 1)$, (X0 dan $\mathrm{X} 2)$, (X0 dan $\mathrm{X} 3)$, (X1 dan $\mathrm{X} 2),(\mathrm{X} 1$ dan $\mathrm{X} 3)$, dan (X2 dan X3). Hasil uji kalsium pada penelitian ini yang menyatakan semakin tingginya penambahan tepung daun kelor dalam pembuatan biskuit maka kalsium juga semakin meningkat. Kadar kalsium tertinggi terdapat pada perlakuan X3 yaitu biskuit dengan penambahan tepung daun kelor sebesar $15 \mathrm{~g}$ dengan kadar kalsium 5159,8 mg. Hasil ini selaras dengan penelitian yang dilakukan oleh Majid et al, yang menyatakan bahwa setelah melakukan pembuatan flakes dengan penambahan tepung daun kelor 5\%, 7,5\% dan 10\% diketahui bahwa hasil analasis kalsium meningkat. Kadar kalsium tertinggi pada flakes dengan proporsi daun kelor sebesar $10 \%{ }^{13}$. Berdasarkan uji kalsium biskuit dipaparkan pada gambar 2 .

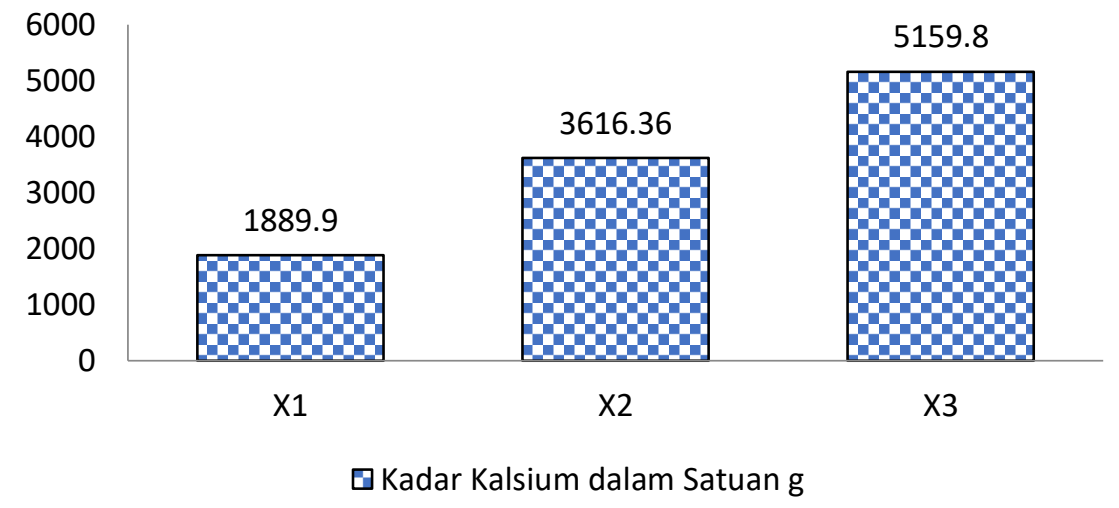

Gambar 2. Kadar Kalsium dalam 3 Taraf Perlakuan pada Biskuit

Pada saat uji kesukaan (uji hedonik), panelis mengemukakan tingkat kesukaannya atau skala hedonik dan dimintakan tanggapan pribadinya tentang kesukaan ${ }^{14}$. Hasil uji statistik anova uji daya terima diketahui niali signifikansi 0,911>0,05, maka dapat dinilai bahwa tidak ada perbedaan yang signifikan diantara ke 4 daya terima biskuit.Uji daya terima ini meliputi aroma, warna, rasa, dan tekstur terhadap 4 taraf perlakuan biskuit ubi jalar ungu tanpa atau dengan penambahan tepung daun kelor.diuraikan sebagai berikut:

Tabel 1. Daya Terima Kesukaan Panelis terhadap Produk Biskuit (Aroma, Warna, Rasa, Tekstur)

\begin{tabular}{|c|c|c|c|c|c|c|c|}
\hline Daya Terima & $\mathbf{n}$ & Rata-rata & SD & SE & $\mathbf{9 5 \%}$ CI & minimum & maximum \\
\hline Aroma & 4 & 1,98 & 0,44 & 0,23 & $1,27-2,71$ & 1,32 & 2,28 \\
\hline Warna & 4 & 2,07 & 0,38 & 0,19 & $1,46-2,67$ & 1,56 & 2,48 \\
\hline Rasa & 4 & 1,88 & 0,67 & 0,34 & $0,82-2,95$ & 1,18 & 2,48 \\
\hline Tekstur & 4 & 2,11 & 0,33 & 0,16 & $1,59-2,63$ & 1,68 & 2,40 \\
\hline Total & 16 & 2,02 & 0,43 & 0,11 & $1,78-2,24$ & 1,18 & 2,48 \\
\hline
\end{tabular}

a. Aroma

Aroma yang paling disukai panelis adalah aroma biskuit $\mathrm{X} 1$ memiliki nilai daya terima aroma dengan rata-rata tertinggi yaitu sebesar 2,28 sedangkan untuk daya terima aroma 
dengan rata-rata terendah yaitu biskuit $\mathrm{X} 3$ yaitu 1,32. Hasil ini selaras dengan penelitian yang dilakukan oleh Zakaria dan Rauf yang menyatakan bahwa kesukaan panelis terhadap aroma cenderung menurun dengan semakin meningkatnya penambahan tepung daun kelor, 3 - $12 \%$ rata-rata agak suka (43,73 - 64,48\%), sementara pada konsentrasi $12 \%$, panelis menyatakan tidak suka ${ }^{15}$. Sementara pada penelitian lain menyatakan penilaian daya terima panelis terhadap aroma cookies menunjukkan bahwa semakin banyak substitusi tepung daun kelor dan tepung kecambah kedelai maka semakin rendah pula tingkat kesukaan panelis ${ }^{16}$. Hal ini juga selaras dengan penelitian Trisnawati yang menyatakan bahwa semakin banyak konsentrat daun kelor yang ditambahkan dapat mengakibatkan aroma langu semakin menyengat ${ }^{17}$.

\section{b. Warna}

Skala penilaian tertinggi adalah perlakuan $\mathrm{X} 1$ dengan rata-rata penilaian panelis sebesar 2,48 , sedangkan taraf perlakuan dengan skala penilaian terendah adalah perlakuan X3 yang merupakan biskuit dengan rata-rata penilaian panelis sebesar 1,56. Hasil ini selaras dengan penelitian yang dilakukan sebelumnya yang menyatakan semakin besar penambahan tepung daun kelor mempengaruhi warna flakes semakin berwarna pekat dan tidak disukai oleh panelis ${ }^{13}$. Penelitian ini sejalan dengan penelitian yang dilakukan sebelumnya oleh Sari dan Adi yang menyatakan bahwa tingkat kesukaan terhadap warna oleh panelis adalah dengan penambahan tepung daun kelor yang terendah yaitu sebesar $10 \mathrm{~g}$ dengan persentase $80 \%{ }^{16}$.

c. Rasa

Skala penilaian tertinggi adalah perlakuan X0 yang merupakan biskuit ubi jalar ungu tanpa penambahan tepung daun kelor dengan rata-rata penilaian panelis sebesar 2,48, sedangkan taraf perlakuan dengan skala penilaian terendah adalah perlakuan X3 dengan rata-rata penilaian panelis sebesar 1,44. Hal ini juga selaras dengan penelitian yang dilakukan oleh Sari dan Adi menyatakan bahwa rasa yang dihasilkan oleh cookies ini dipengaruhi oleh adanya tepung daun kelor,tepung kecambah kedelai, mentega, gula, dan susu ${ }^{16}$. Hasil penilaian daya terima terhadap rasa cookies disajikan pada tabel dengan kesimpulan bahwa semakin tinggi proporsi tepung daun kelor dan tepung kecambah kedelai maka panelis semakin tidak menyukai rasa cookies. Trisnawati dan Nisa yang menyatakan bahwa semakin banyak konsentrat daun kelor yang ditambahkan dapat mengakibatkan rasa pahit semakin kuat ${ }^{17}$.

d. Tekstur

Taraf perlakuan yang memiliki skala penilaian tertinggi adalah perlakuan X1 sebesar 2,4, sedangkan taraf perlakuan dengan skala penilaian terendah adalah perlakuan X3 sebesar 1,68. Hal ini selaras dengan penelitian yang dilakukan oleh Sari dan Adi yang menyatakan bahwa formula F2 memiliki persentase tertinggi kategori suka (96,7\%). Perbedaan proporsi tepung daun kelor dan tepung kecambah kedelai menjadikan panelis memiliki tingkat kesukaan terhadap tekstur yang berbeda pula. Semakin banyak penambahan tepung daun kelor dan tepung kecambah menjadikan cookies semakin keras, hal ini terjadi karena kedua tepung tersebut mengandung protein yang cukup tinggi, sedangkan untuk membuat cookies yang digunakan adalah tepung rendah protein agar tekstur yang dihasilkan lebih renyah ${ }^{16}$. Dan juga selaras dengan penelitian sebelumnya 
yang dilakukan oleh Kholis dan Hadi yang menyatakan bahwa biskuit yang terbuat terbuat dari susu sebagai kelompok kontrol lebih renyah daripada biskuit dengan penambahan tepung daun kelor ${ }^{18}$.

Tabel 1. Daya Terima Kesukaan Panelis terhadap Produk Biskuit (Aroma, Warna, Rasa, Tekstur)

\begin{tabular}{|l|c|c|c|c|c|}
\hline Sumber variasi & Jumlah kuadrat & Df & $\begin{array}{c}\text { Rata-rata } \\
\text { kuadrat }\end{array}$ & F & $\boldsymbol{p}$ \\
\cline { 1 - 4 } Antar perlakuan & 0,119 & 3 & 0,040 & 0,175 & 0,911 \\
\cline { 1 - 4 } Dalam perlakuan & 2,716 & 12 & 0,226 & & \\
\hline Total & 2,835 & 15 & & & \\
\hline
\end{tabular}

\section{Kesimpulan}

Kadar protein dan kalsium pada biskuit mengalami peningkatan seiring dengan penambahan tepung daun kelor sebesar $5 \mathrm{~g}, 10 \mathrm{~g}$ dan $15 \mathrm{~g}$. Biskuit yang paling disukai oleh panelis dari segi aroma, warna dan tekstur adalah biskuit dengan penambahan kelor $5 \mathrm{~g}$, sedangkan dari segi rasa adalah rasa adalah X0. Berdasarkan hasil uji analisis laboratorium dan uji Hedonic scale test biskuit ubi jalar ungu dengan penambahan tepung daun kelor yang memiliki tingkat daya terima tertinggi dan direkomendasikan adalah biskuit dengan penambahan tepung daun kelor $5 \mathrm{~g}$ dengan kalori $45,4 \mathrm{kkal}$, protein 0,77g dan kalsium 13,68 mg serta memiliki kandungan protein 9,54\%. Hasil analisis laboratorium tersebut lebih tinggi jika dibandingkan dengan Persyaratan Mutu Biskuit (SNI 01-2973-2011) dan biskuit dari program PMT yang diberikan oleh pemerintah dan disukai panelis. Saran yang diberikan peneliti bagi Dinas Kesehatan Kabupaten Jember adalah produk ini dapat diwujudkan sebagai alternatif makanan selingan yang sehat untuk anak-anak sebagai langkah mengurangi konsumsi jajanan tidak sehat, untuk menunjang pertumbuhan anak-anak dengan asupan protein dan kalsium yang cukup untuk memenuhi syarat PMT, serta untuk mendukung pemerintah dalam program diversifikasi pangan dan sebagi PMT Posyandu berbasis pangan lokal. Dan untuk masyarakat Adanya produk biskuit ubi jalar ungu dengan penambahan tepung daun kelor diharapkan dapat memberikan inovasi baru dibidang pangan serta meningkatkan nilai ekonomis dari tepung ubi jalar ungu dan tepung daun kelor.

\section{Referensi}

1. Ahira, D. 2010. Pertumbuhan Fisik Balita. [serial online]. http://ahirapertumbuhanfisikbalita.htp. [2 Februari 2019]

2. Soetjiningsih dan Ranuh, IG.N.2013. Tumbuh Kembang Anak Edisi 2. Jakarta: Penerbit Buku Kedokteran EGC.

3. Rahim, Fitri Kurnia. 2014. Faktor Risiko Underweight Balita umur 7-59 Bulan. Semarang: Jurnal Kesehatan Masyarakat.

4. Kementerian Kesehatan RI. 2017. Buku Saku Pemantauan Status Gizi Tahun 2017. Jakarta: Kementerian Kesehatan RI 
5. Susilowati, dan Kuspriyanto. 2016. Gizi Dalam Daur Hidup Kehidupan . Jakarta: Refika Aditama

6. Diantoro, A., Rohman, M., Budiarti, R. dan Palupi, H.T. 2015. Pengaruh Penambahan Ekstrak Daun Kelor (Moringa oleifera) terhadap Kualitas Yogurt. Jurnal Teknologi Pangan Vol. 6 No.2.

7. Winarti, S. 2010. Jenis-Jenis Bahan Pangan Fungsional. Yogyakarta: Graha Ilmu.

8. Hardono, G. S. 2014. Strategi Pengembangan Diversifikasi Pangan Lokal. Bogor: Pusat Sosial Ekonomi dan Kebijakan Pertanian. Analisis Kebijakan Pertanian. Volume 12 No. 1, Juni 2014: 1-17.

9. Augustyn, G.H., Tuhumury H.C.G., dan Dahoklory, M. 2017. Pengaruh Penambahan Tepung Daun Kelor (Moringa oleifera) tehadap Karakteristik Organoleptik dan Kimian Biskuit mocaf (Modified Cassava Flour). Ambon: Jurnal Teknologi Pertanian.

10. Nazir. 2014. Metode Penelitian. Bogor: Ghalia Indonesia.

11. Notoatmodjo, S. 2012. Metodologi Penelitian Kesehatan. Jakarta: PT Rineka Cipta.

12. Rudianto, Syam \& Alharini. 2013. Studi Pembuatan dan Analisis Zat Gizi pada Produk Biskuit Moringa oleifera dengan Substitusi Tepung Daun Kelor. repository.unhas.ac.id [diakses secara online pada tanggal 4 Oktober 2019]

13. Majid F.R.,Hidayat N., dan Waluyo. 2017. Variasi Penambahan Tepung Kelor (Moringa oleifera Lam.) pada pertumbuhan Flakes ditinjau dari Sifat Fisik, Sifat Organoleptik, dan Kadar Kalsium. Jurnal Nutrisia, Vol. 19 Nomor 1, halaman 31-35.

14. Setyaningsih, Apriyantono, A., \& Puspitasari, M.2012. Analisis Sensori untuk Industri Pangan dan Agro. Bogor: IPB Press

15. Zakaria dan Rauf S. 2017. Optimalisasi Pembuatan Mie Basah dengan Penambahan Tepung Daun Kelor (Moringa oleifara). Makassar: Media Pangan Gizi Media Gizi Pangan, Vol. XXIV, Edisi 2

16. Sari, K. Y., dan Adi, A. C. 2017. Daya Terima, Kadar Protein dan Zat Besi Cookies Subtitusi Tepung Daun Kelor dan Tepung Kecambah Kedelai. Media Gizi Indonesia, Vol. 12, No. 1 Januari-Juni 2017: hlm. 27-33.

17. Trisnawati, M., dan Nisa, F. 2015. Pengaruh Penambahan Konsentrat Protein Daun Kelor dan Karagenan Terhadap Kualitas Mie Kering Tersubtitusi Mocaf. Malang : Jurnal Pangan dan Agroindustri Vol. 3 No 1 p.237-24.

18. Hadi, F., \& Kholis, N. 2010. Pengujian Bioassay Biskuit Balita yang Disuplementasi Konsentrat Protein Daun Kelor (Moringa oleifera) pada Model Tikus Malnutrisi. Jurnal Teknologi Pertanian Vol.11 No.3, 144-151. 